\title{
PENERAPAN METODE PROBLEM SOLVING MELALUI ALAT PERAGA TEMPEL POLA KALIMAT (PELPOKA) UNTUK MENINGKATKAN KEMAMPUAN MENGENAL CERITA PADA SISWA KELAS V TUNARUNGU DI SLB NEGERI TALUN KABUPATEN BLITAR SEMESTER GANJIL TAHUN PELAJARAN 2020 /2021
}

\author{
SRI HARTATI \\ SDLBN KENDALREJO TALUN KAB.BLITAR,PROPINSI JAWA TIMUR \\ Coresponding Email : sriondong@gmail.com
}

\begin{abstract}
ABSTRAK
Penelitian Ini Bertujuan Untuk: (1) Mendeskripsikan Penerapan Metode Problem Solving Melalui Alat Peraga Peraga Tempel Pola Kalimat (Pelpoka) Untuk Meningkatkan Minat Belajar Tentang Mengenal Kalimat Pada Siswa Kelas V Tunarungu Di SDLB Negeri Talun Kabupaten Blitar Semester Ganjil Tahun Pelajaran 2020/2021; (2) Mendeskripsikan Penerapan Metode Problem Solving Melalui Alat Peraga Tempel Pola Kalimat (Pelpoka) Untuk Meningkatkan Hasil Belajar Tentang Mengenal Cerita Pada Siswa Kelas V Tunarungu Di Slb Negeri Talun Kabupaten Blitar Semester Ganjil Tahun Pelajaran 2020/2021. Penelitian Ini Dilakukan Pada Semester Ganjil Tahun Pelajaran 2020/2021. Materi Tentang Kemampuan Mengenal Kalimat Pada Kelas V Dengan Metode Pembelajaran Problem Solving Melalui Alat Peraga Tempel Pola Kalimat (Pelpoka). Penelitian Ini Menggunakan Desain Penelitian Tindakan Kelas (Ptk). Kesimpulan Penelitian Ini Ialah Sebagai Berikut: (1) Penerapan Metode Problem Solving Melalui Alat Peraga Pelpoka Mempunyai Pengaruh Positif, Yaitu Dapat Meningkatkan Minat Belajar Siswa Yang Ditunjukan Dengan Peningkatan Prosentase Minat Belajar Siswa Dari Siklus I Sebesar 66,00\% Dan Meningkat Pada Siklus Ii Menjadi 100\%, Artinya Pada Siklus Ini Minat Belajar Kategori Sangat Aktif. Jadi, Dari Siklus I Ke Siklus Ii Ada Peningkatan Minat Belajar Sebesar 25,00\%; (2) Hasil Belajar Materi Bahasa Indonesia Pada Materi Pokok Kemampuan Mengenal Cerita Kelas V Tunarungu Slb Negeri Talun, Kabupaten Blitar Dapat Meningkat Dengan Penerapan Metode Problem Solving Melalui Alat Peraga Tempel Pola Kalimat (Pelpoka). Hal Ini Dapat Dilihat Bahwa Pada Siklus I, Dari 3 Siswa Yang Tuntas Sebanyak 1 Siswa (33\%) Dan Yang Belum Tuntas Hanya Sebanyak 2 Siswa (66\%). Sedangkan Pada Siklus Ii, Siswa Yang Tuntas Semua Siswa (100\%) Dan Tidak Ada Yang Belum Tuntas (0\%). Dari Siklus I Ke Siklus Ii Ada Peningkatan Hasil Belajar Sebesar 66 \%.

Kata Kunci : Metode Problem Solving, , Mengenal Alat Peraga Tempel Pola Kalimat
\end{abstract} (Pelpoka) , Tunarungu 


\section{PENDAHULUAN}

Materi Bahasa Indonesia merupakan salah satu pelajaran penting di Sekolah Luar Biasa (SLB) yang perlu mendapatkan perhatian khusus, sebab Materi Bahasa Indonesia dapat mempersiapkan siswa agar mampu menggunakan pola kalimat dalam kehidupan sehari-hari dan dalam mempelajari berbagai ilmu. Materi Bahasa Indonesia perlu diberikan kepada semua peserta didik mulai dari sekolah dasar karena bahasa Indonesia merupakan mata pelajaran yang harus diajarkan kesemua jenjang pendidikan. Untuk membekali peserta didik dengan kemampuan memahami dan menggunakan bahasa Indonesia secara efektif dan efisien baik tulis maupun tulisan. Pembelajaran Bahasa Indonesia di SD saat ini mencangkup seluruh aspek kebahasaan yaitu menyimak, berbicara , membaca, dan menulis. Menurut Goodman (2004) dan Suparti (2007), siswa akan lebih mudah belajar Bahasa jika pembelajaran bersifat nyata, relevan, kontektual, dan bermakna . Bahasa Indonesia sebagai alat komunikasi formal, memahami, dan menggunakan yang tepat serta bangga menjadikan bahasa Indonesia sebagai budaya Indonesia.

Berdasarkan pengamatan awal diperoleh data tentang hasil belajar siswa kelas V di SLB Negeri Talun, Kabupaten Blitar masih dikatakan rendah. Dari 3 siswa yang mengikuti pembelajaran, hanya 1 (33\%) yang tergolong aktif, dan 2 siswa lainnya $(66 \%)$ masih tergolong pasif. Sedangkan, hasil belajar siswa Materi Bahasa Indonesia pada siswa kelas V di SLB Negeri Talun, Kabupaten Blitar juga masih dikatakan sangat rendah. Hal itu terbukti dari 3 siswa yang mengikuti ulangan harian tersebut, hanya 1 siswa (33\%) yang tuntas, dan terdapat 2 siswa (66 \%) belum tuntas, artinya mencapai di bawah KKM yaitu 74. Dengan demikian, secara klasikal sebelum dilakukan penelitian tindakan kelas ini, hasil belajar Materi bahasa Indonesia pada siswa Kelas V Tunarungu SLB Negeri Talun, Kabupaten Blitar dapat dikatakan masih belum tuntas.

Rendahnya hasil belajar tersebut disebabkan oleh beberapa faktor, yaitu: (1) Guru terlalu banyak menggunakan metode ceramah sehingga potensi kritis siswa tidak optimal, (2) Guru sering memberikan gambar tanpa ada penjelasan , (3) Kurangnya kesempatan berinteraksi antara guru dengan siswa, dan siswa dengan siswa, hal ini menyebabkan siswa kurang mendapatkan pengalaman belajar dari temannya atau pun guru, serta (4) Kurangnnya waktu yang diberikan kepada siswa untuk berinteraksi dengan media atau alat peraga (Prayanti:2001)

Agar pembelajaran bahasa Indonesia dapat mencapai tujuannya ada beberapa hal yang perlu diperhatikan dalam melaksanakan kegiatan pembelajaran Materi Bahasa Indonesia adalah: (1) mengkondisikan siswa untuk menemukan kembali konsep atau prinsip dalam materi bahasa Indonesia melalui bimbingan guru agar siswa terbiasa melakukan pengamatan dan menemukan sesuatu, (2) pendekatan pemahaman kalimat merupakan fokus dalam pembelajaran bahasa Indonesia yang mencakup masalah tertutup, mempunyai solusi tunggal, terbuka atau masalah dengan berbagai cara penyelesaian, (3) beberapa keterampilan untuk meningkatkan kemampuan memecahkan masalah.

Ruang lingkup materi bahasa Indonesia peserta didik Tunarungu kelas V di SLB Negeri Talun adalah menggali informasi, menguraikan, dan menyajikan teks 
sederhana baik lisan maupun tulisan dengan memperhatikan penggunaan kata dan kalimat yang efektif dan efesiensi dengan tujuan akhir untuk mengembangan kemampuan berbahasa dan berkomunikasi.

Selain itu, peserta didik Tunarungu di SLB Negeri Talun dapat memperlajari bahasa Indonesia untuk meningkatkan kemampuan intelektual serta kematangan emosional dan sosial, memanfaatkan karya sastra untuk memperluas wawasan, memperhalus budi pekerti serta meningkatkan pengetahuan, dan pada akhirnya memiliki kemampuan dalam berbahasa dan berkomunikasi secara lisan maupun tulisan secara efektif dan efisiensi. Pembelajaran bahasa Indonesia dilakukan dalam rangka mencapai kompetensi sikap spiritual, sikap sosial, pengetahuan dan ketrampilan. Pengembangan kompetensi sikap spiritual dan sikap sosial dilaksanakan melalui pembelajaran tidak langsung .

Berdasarkan uraian tersebut, sebagai alternatif solusi maka penulis mencoba menerapkan salah satu metode pembelajaran, yaitu metode pembelajaran Problem Solving. Metode Problem Solving adalah suatu proses pembelajaran yang melakukan pemusatan pada pengajaraan dan keterampilan pemecahan maslah yang dikuti dengan penguatan keterampilan. Dalam hal ini masALAH didefinisikan sebagai suatu persoalan yang tidak rutin dan belum dikenal cara penyelesaiannya. Selain itu, melalui Problem Solving mampu mencari atau menentukan cara penyelesaian (Arus Sohimin:2014).

Berdasarkan latar belakang di atas, maka perlu dilakukan penelitian dengan tujuan untuk perbaikan pembelajaran bahasa Indonesia melalui Penelitian Tindakan Kelas dengan judul: "Penerapan Metode Problem Solving Melalui Alat Peraga Pola Tempel Kalimat (PELPOKA) Untuk Meningkatkan Kemampuan Mengenal Cerita Pada Siswa Kelas V Tunarungu di SLB Negeri Talun Kabupaten Blitar Semester Ganjil Tahun Pelajaran 2020/2021 ."

\section{METODE PENELITIAN}

Tempat penelitian pembelajaran ini dilaksanakan di SLB Negeri Talun, Kabupaten Blitar. Adapun waktu penelitian pembelajaran ini dilakukan pada semester ganjil tahun pelajaran 2020 /2021. Materi bahasa Indonesia tentang kemampuan menyusun kalimat pada kelas V dengan metode pembelajaran Problem Solving melalui alat peraga Pelpoka.Waktu penelitian ini dilaksanakan dalam dua siklus. Siklus I pada tanggal 09 - 11 September 2020. Siklus II pada tanggal 23 - 25 September 2020 dan disesuaikan dengan jadwal pelajaran di sekolah. Subjek penelitian tindakan kelas ini adalah siswa kelas V Tunarungu SLB Negeri Talun, Kabupaten Blitar, dengan jumlah 3 siswa yang bernama Dewiana, Bagaswara, dan Enjang. Pihak yang membantu dalam melaksanakan proses penelitian ini yaitu teman sejawat dan kepala sekolah. Penelitian ini menggunakan desain penelitian tindakan kelas (PTK). Pada hakekatnya PTK merupakan suatu proses dimana melalui proses ini guru menginginkan adanya perbaikan, peningkatan, dan perubahan pembelajaran lebih baik agar tujuan pembelajaran dapat tercapai secara optimal. Desain penelitian ini dilaksanakan dalam dua siklus. 


\section{HASIL PENELITIAN DAN PEMBAHASAN}

\section{a) Deskripsi Hasil Penelitian}

\section{Siklus I}

a. Perencanaan

Tindakan siklus I dilaksanakan pada tanggal 09 - 11 September 2020. Waktu yang dibutuhkan yaitu dua pertemuan, masing-masing dua jam pelajaran atau 2 x 35 menit. Pelaksanaan pembelajaran pada Siklus I ini sesuai dengan Rencana Pelaksanaan Pembelajaran (RPP) I, yang disusun dengan langkah-langkah pembelajaran yang meliputi: kegiatan awal, kegiatan inti, dan kegiatan akhir.

b. Pelaksanaan Tindakan Siklus I

Observasi dilaksanakan bersama proses pembelajaran melalui lembar pengamatan yang meliputi, aktifitas siswa, pengembangan materi, motivasi siswa dalam kegaitan pembelajaran, proses pembelajaran, serta hasil pembelajaran melalui tes akhir. Pada pertemuan I Siklus I, pelaksanaan observasi partisipasi siswa dalam pembelajaran Materi bahasa Indonesia kelas V tentang Kemampuan Mengenal kalimat, hanya 1 siswa dengan kategori aktif dan 2 siswa yang pasif. Sehingga, prosentase keaktifan siswa masih sebesar 33 $\%$. Sedangkan, pada pertemuan II Siklus II, pelaksanaan observasi partisipasi siswa dalam pembelajaran materi bahasa Indonesia kelas $\mathrm{V}$ tentang Kemampuan Mengenal Kalimat melalui Alat Peraga Pelpoka , terdapat 2 siswa dengan kategori aktif dan 1 siswa dengan kategori pasif. Sehingga, prosentase keaktifan siswa sebesar $66 \%$. Dengan demikian rata-rata minat belajar siswa pada Siklus II sebesar $66 \%$.

Tabel 1. Minat Belajar Kelas V Siklus I

\begin{tabular}{ccccc}
\hline & \multicolumn{2}{c}{ Pertemuan I } & \multicolumn{2}{c}{ Pertemuan II } \\
\cline { 2 - 5 } & Aktif & Pasif & Aktif & Pasif \\
\hline Jumlah & $\mathbf{1}$ & $\mathbf{2}$ & $\mathbf{2}$ & $\mathbf{1}$ \\
\hline Prosentase & $33 \%$ & $66 \%$ & $66 \%$ & $33 \%$ \\
\hline
\end{tabular}

Data hasil belajar pada kegiatan siklus I yang diambil kepada siswa di akhir kegiatan Siklus I. Secara terperinci hasil belajar Materi bahasa Indonesia pada materi Kemampuan Mengenal Kalimat dapat dijelaskan pada tabel berikut ini: 
Tabel 2. Hasil Belajar Kelas V Siklus I

\begin{tabular}{ccc}
\hline No. & Rentang & Jumlah siswa \\
\hline 1. & $90-100$ & 0 \\
\hline 2. & $80-89$ & 0 \\
\hline 3. & $70-79$ & 1 \\
\hline 4. & $60-69$ & 1 \\
\hline 5. & $50-59$ & 1 \\
\hline 6. & $0-49$ & 0 \\
\hline
\end{tabular}

Ketuntasan kelas $=$ jumlah Siswa yang Tuntas $\mathrm{x} 100 \%$

Jumlah Total Siswa

Ketuntasan kelas $=\frac{1}{3} \times 100 \%=\mathbf{3 3 \%}$

c. Refleksi

Dalam pelaksanaan kegiatan belajar mengajar diperoleh informasi dari hasil pengamatan sebagai berikut:

1) Kelebihan

a) Metode Problem Solving melalui alat peraga Pelpoka sudah dapat diterapkan dalam mengurangi metode konvensional atau ceramah yang sering digunakan selama ini.

b) Ketuntasan hasil belajar mengalami peningkatan dari $\mathbf{0 \%}$ (sebelum siklus) menjadi $33 \%$ (setelah siklus I).

c) Prosentase minat belajar juga mengalami peningkatan dari $33 \%$ menjadi $66 \%$.

2) Kelemahan:

a) Pada siklus I masih belum menunjukkan hasil yang memuaskan bahwa kemampuan siswa dalam memahami kalimat melalui Metode Problem Solving melalui alat peraga Pelpoka .

b) Sekalipun ketuntasan minat dan hasil belajar siswa mengalami peningkatan dari sebelum siklus dengan setelah siklus I, namun belum mencapai ketuntasan yaitu 70,00\%.

3) Fakor Yang Menyebabkan:

a) Guru kurang baik dalam memotivasi siswa dan menyampaikan tujuan pembelajaran

b) Guru kurang baik dalam pemanfaatan media pembelajaran.

c) Siswa juga kurang begitu antusias selama pembelajaran berlangsung.

4) Alasan Tindakan Perbaikan:

a) Karena ketuntatas hasil belajar siswa secara klasikan belum mencapai ketuntasan yaitu 66,00\%.

b) Karena penerapan metode Problem Solving melalui alat peraga Pelpoka pada siklus I kurang maksimal dalam memotivasi siswa. 


\section{Siklus II}

\section{a. Perencanaan}

Tindakan siklus II dilaksanakan pada tanggal 23 - 25 September 2020 . Waktu yang dibutuhkan yaitu dua pertemuan dan masing-masing dua jam pelajaran atau 2 x 35 menit. Pelaksanaan pembelajaran pada Siklus II ini sesuai dengan Rencana Pelaksanaan Pembelajaran (RPP) II yang disusun dengan langkah-langkah pembelajaran yang meliputi: kegiatan awal, kegiatan inti, dan kegiatan akhir.

b. Pelaksanaan Tindakan Siklus II

Observasi dilaksanakan bersama proses pembelajaran melalui lembar pengamatan yang meliputi, aktifitas siswa, pengembangan materi, motivasi siswa dalam kegiatan pembelajaran, proses pembelajaran, serta hasil pembelajaran melalui tes akhir. Pada siklus II ini peneliti berusaha untuk memperbaiki kekurangan dan kelemahan pada siklus I. Pada pertemuan I Siklus II, pelaksanaan observasi partisipasi siswa dalam pembelajaran Materi Bahasa Indonesia kelas $\mathrm{V}$ tentang Kemampuan Mengenal urutan kalimat ialah sebagai berikut 2 siswa masuk dalam kategori aktif dan 1 siswa masuk dalam kategori apasif, Sehingga, prosentase keaktifan siswa sebesar $66 \%$.

Sedangkan, pada pertemuan II Siklus II, pelaksanaan observasi partisipasi siswa dalam pembelajaran Materi Bahasa Indonesia kelas V tentang Kemampuan Mengenal urutan kalimat, termasuk dalam kategori aktif dan tidak ada siswa yang pasif. Sehingga, prosentase keaktifan siswa sebesar $100 \%$. Dengan demikian rata-rata minat belajar siswa pada Siklus II sebesar 100\%.

\section{Tabel 3. Minat Belajar Kelas V Siklus II}

\begin{tabular}{ccccc}
\hline & \multicolumn{2}{c}{ Pertemuan I } & \multicolumn{2}{c}{ Pertemuan II } \\
\cline { 2 - 5 } & Aktif & Pasif & Aktif & Pasif \\
\hline Jumlah & $\mathbf{2}$ & $\mathbf{1}$ & $\mathbf{3}$ & $\mathbf{0}$ \\
\hline Prosentase & $66 \%$ & $33 \%$ & $100 \%$ & $0 \%$ \\
\hline
\end{tabular}

Data hasil belajar pada kegiatan siklus II yang diambil dari siswa di akhir kegiatan Siklus II. Secara terperinci hasil belajar materi Bahasa Indonesia pada materi Kemampuan Mengenal kalimat dapat dijelaskan pada tabel berikut:

Tabel 4. Hasil Belajar Kelas V Siklus II

\begin{tabular}{ccc}
\hline No. & Rentang & Jumlah siswa \\
\hline 1. & $90-100$ & 0 \\
\hline 2. & $80-89$ & 1 \\
\hline 3. & $70-79$ & 2 \\
\hline 4. & $60-69$ & 0 \\
\hline 5. & $50-59$ & 0 \\
\hline 6. & $0-49$ & 0 \\
\hline
\end{tabular}


Ketuntasan kelas $=\underline{\text { Jumlah Siswa yang Tuntas x } 100 \%}$

Jumlah Total Siswa

Ketuntasan kelas $=\frac{3}{3} \mathrm{x} 100 \%=\mathbf{1 0 0 \%}$

c. Refleksi

Dengan melihat tabel dan grafik minat serta hasil belajar di atas, dapat diketahui bahwa hasil belajar pada siklus II tentang Kemampuan Mengenal Kalimat dengan Metode Problem Solving melalui alat peraga Pelpoka mengalami peningkatan yang cukup pesat yaitu semua siswa (100\%) sudah berhasil, sesuai dengan KKM bahkan ada yang di atas KKM di SLB Negeri Talun kabupaten Blitar. Hasil tersebut menunjukkan bahwa pada siklus II secara klasikal siswa telah tuntas, karena siswa yang memperoleh nilai di atas KKM lebih besar dari prosentase ketuntasan yang dikehendaki yaitu sebesar $100 \%$. Sedangkan, prosentase partisipasi juga sebesar $100 \%$, artinya pada Siklus II ini partisipasi kategori sangat aktif.

Adapun perbandingan antara kedua Siklus di atas, baik hasil belajar maupun tingkat minat belajar dapat dilihat pada tabel berikut ini:

Tabel 6. Perbandingan Minat Belajar Siklus I dan II

\begin{tabular}{|l|c|c|}
\hline \multicolumn{1}{|c|}{ Kategori } & Rata-Rata Siklus I & Rata-Rata Siklus II \\
\hline Aktif & $50 \%$ & $83 \%$ \\
\hline Pasif & $50 \%$ & $33 \%$ \\
\hline $\begin{array}{l}\text { Peningkatan Partisipasi } \\
\text { Belajar Siswa }\end{array}$ & \multicolumn{2}{|c|}{$83 \%-33 \%=\mathbf{5 0 \%}$} \\
\hline
\end{tabular}

Tabel 7. Perbandingan Hasil Belajar Siklus I dan II

\begin{tabular}{|l|c|c|c|c|}
\hline \multicolumn{1}{|c|}{ Kategori } & \multicolumn{2}{c|}{ Siklus I/Prosentase } & \multicolumn{2}{c|}{ Siklus II/Prosentase } \\
\hline Tuntas & 2 & $66 \%$ & 3 & $100 \%$ \\
\hline Belum Tuntas & 1 & $33 \%$ & 0 & $0 \%$ \\
\hline $\begin{array}{l}\text { Peningkatan Hasil } \\
\text { Belajar Siswa }\end{array}$ & \multicolumn{3}{|c|}{$100 \%-66 \%=\mathbf{3 4 \%}}$. \\
\hline
\end{tabular}

Dari Hasil penelitian pembelajaran pada siklus I, untuk meningkatan hasil belajar Materi bahasa Indonesia tentang Kemampuan Mengenal Kalimat melalui metode Problem Solving dengan alat peraga di kelas V Tunarungu SLB Negeri Talun, Kabupaten Blitar masih belum sepenuhnya dipahami anak. Beberapa hal yang menyebabkan ialah:

a. Metode yang diterapkan guru masih belum bisa membuat siswa aktif secara maksimal dalam pembelajaran di kelas.

b. Prosentase minat belajar siswa pada Siklus I hanya sebesar 50\%, artinya pada Siklus ini minat belajar masih kategori pasif. 
c. Hasil akhir siklus pembelajaran ke I ini semakin meningkat dibanding sebelum siklus, dari rata-rata ketuntasan $0 \%$ menjadi 33\%. Namun, secara klasikal belum tuntas.

Pada siklus II ini pengamatan yang diperoleh adalah:

a. Metode yang diterapkan guru sudah berjalan dengan maksimal. Komunikasi antar guru dan siswa juga sangat aktif karena guru memperhatikan dan menghargai ide atau pendapat siswa.

b. Semangat siswa dalam mengikuti pembelajaran semakin meningkat karena pembelajaran dengan metode yang lebih jelas dan terarah.

c. Prosentase minat belajar siswa pada Siklus II telah meningkat dari $33 \%$ menjadi $100 \%$, artinya pada siklus ini minat belajar kategori sangat aktif.

d. Hasil akhir siklus pembelajaran ke II ini semakin meningkat dibanding siklus I, dari rata-rata ketuntasan 33\% menjadi 100\%. Dengan demikian, secara klasikal hasil belajar materi bahasa Indonesia dinilai tuntas.

\section{KESIMPULAN}

Dari Penelitian Tindakan Kelas yang dilakukan peneliti dapat diambil kesimpulan bahwa:

1. Penerapan Metode Problem Solving Melalui Alat Peraga Pelpoka mempunyai pengaruh positif, yaitu dapat meningkatkan minat belajar siswa yang ditunjukan dengan peningkatan prosentase minat belajar siswa dari Siklus I sebesar $33 \%$ meningkat pada Siklus II menjadi $100 \%$, artinya pada Siklus ini minat belajar kategori sangat aktif. Jadi, dari Siklus I ke Siklus II ada peningkatan minat belajar sebesar $67 \%$.

2. Hasil belajar materi bahasa Indonesia pada materi pokok Kemampuan Mengenal Kalimat Kelas V Tunarungu SLB Negeri Talun, Kabupaten Blitar dapat meningkat dengan penerapan Metode Problem Solving melalui Alat Peraga Pelpoka . Hal ini dapat dilihat bahwa pada Siklus I pertemuan II, dari 3 siswa yang tuntas sebanyak 2 siswa (66\%) dan yang belum tuntas hanya sebanyak 1 siswa (33\%). Sedangkan pada Siklus II, siswa yang tuntas semua siswa (100\%) dan tidak ada yang belum tuntas $(0 \%)$. Dari Siklus I ke Siklus II ada peningkatan hasil belajar sebesar $66 \%$.

3. Untuk melaksanakan Metode Problem Solving Melalui Alat peraga Pelpoka memerlukan persiapan yang cukup matang. Sehingga, guru harus mampu menentukan atau memilih topik yang benar-benar bisa diterapkan dengan menggunakan metode pembelajaran Problem Solving dalam pembelajaran agar diperoleh hasil yang optimal.

4. Dalam rangka meningkatkan partisipasi dan hasil belajar siswa, guru hendaknya lebih sering melatih siswa dengan berbagai metode pengajaran, walau dalam taraf yang sederhana agar siswa nantinya dapat menemukan pengetahuan baru, memperoleh konsep dan keterampilan. Sehingga, siswa mampu memecahkan masalah-masalah yang dihadapinya. 


\section{DAFTAR PUSTAKA}

Abimanyu, Soli dkk. (2008). Strategi Pembelajaran. Jakarta: Direktorat Jendral Pendidikan Tinggi Departemen Pendidikan Nasional

Arends, Richard I. (2012). Learning to Teach Belajar untuk Mengajar. Terj. Helly Pajitno Soetjipto \& Sri Mulyantini Soetjipto. Yogyakarta: Pustaka Pelajar

Majid, Abdul. (2013). Strategi Pembelajaran. Bandung : PT. Remaja Rosdakarya).

Peraturan Direktur Jenderal Pendas dan Menengah (2017). Struktur kurikulum,Kompetensi Inti, Kompetensi Dasar, dan Pedoman Implementasi Kurikulum Jakarta: Kemdikbud.

Sahlan, Moh, (2007), Penilaian Berbasis Kelas, Jakarta: Rineka Cipta

Sugiyono. (2012). Metode Penelitian Kuantitatif, Kualitatif Dan R\&D. Bandung: Alfabeta.

Sohiman, Arus. (2014). 68 Model Pembelajaran Inovatif Dalam Kurikulum 2013. Yogyakarta: Ar Ruzz Media.

Wardani, dkk, (2014). PemaSntapan Kemampuan Profesional (PKP) - PGSD, Jakarta: Universitas Terbuka. 